\title{
A model using adherence: house compliance center Oasis AAS
}

\author{
Abdoulazziz Soundiata Traoré \\ From $16^{\text {th }}$ International Symposium on HIV and Emerging Infectious Diseases \\ Marseille, France. 24-26 March 2010
}

\section{Background}

Putting in processing a large number of people receiving ARVs needed to enhance adherence to ARV treatment. But this development should be fixed on a new vision. The activities of aid Adherence: being punctual, our profit were delayed or even absent in ARV treatment because they did not have enough information ARVs and even on the resistors. They did not meet the appointment aid activities Adherence: while each visit has a theme. It has not happened has touched all the meetings, that is how the idea of creating a house of adherence is born.

\section{Methods}

The House of adherence is a community center for patient education, promotion of health and readiness to return to active social life of people living with HIV/ AIDS on ARV therapy. In contrast with brief and timely aid to compliance, the specificity of home monitoring is to provide a temporary withdrawal of the living environment which can involve deeper and more lasting quality lives of PLWHA. The House of observance takes a comprehensive approach to compliance that puts decisiontreatment against AIDS in the context of psychological, social and economic life of people and their environment.

\section{Results}

This project allowed people on ARV treatment to integrate into their lifestyle, to help restore equity in access to ARV treatment for people most vulnerable and preparing for expanding access to treatment ARVs. Our approaches were based on psychosocial determinants, medical, economic, political etc.. This house observance is open to all people on ARV therapy, starting treatment

Correspondence: a_soundiata@yahoo.fr

Association African Solidarité, Ouagadougou, Burkina Faso

BioMed Central 2010 Traoré, licensee BioMed Central Ltd or changing treatment. In addition the person must have difficulty taking ARVs, be in good health, does not present a contagious infection, be motivated and committed to participate. It should be noted that 108 people who stayed and after a period of 07 months, $87 \%$ saw their CD4 counts increased by more than $60.8 \%$ under $50 \mathrm{CD} 4,5 \%$ saw their CD4 dropped by over $80 \%$ took more $5 \mathrm{~kg}$, $14 \%$ less than $5 \mathrm{~kg}, 4 \%$ did not change weight and $2 \%$ decreased weight.

\section{Discussion}

This house has had much impact because more than $80 \%$ of persons conducting activities and who was abandoned due to the disease resumed its activities 06 months after their passage home observance. We believe expanding the house of compliance has other associations and replicate within the association.

Published: 11 May 2010

doi:10.1186/1742-4690-7-S1-P167

Cite this article as: Traoré: A model using adherence: house compliance center Oasis AAS. Retrovirology 2010 7(Suppl 1):P167.

Submit your next manuscript to BioMed Central and take full advantage of:

- Convenient online submission

- Thorough peer review

- No space constraints or color figure charges

- Immediate publication on acceptance

- Inclusion in PubMed, CAS, Scopus and Google Scholar

- Research which is freely available for redistribution

Submit your manuscript at www.biomedcentral.com/submit 